\title{
The Old Navarino fortification (Palaiokastro) at Pylos (Greece). Adaptation to early artillery
}

\author{
Xeni Simou \\ University of Patras, Patras, Greece, xeni.simou@gmail.com
}

\begin{abstract}
Old Navarino fortification (Palaiokastro) is located on the promontory supervising the naturally endowed Navarino-bay at the south-western foot of Peloponnese peninsula, near the contemporary city of Pylos. The cliff where it is built and where ancient relics lie, was fortified by Frankish in the thirteenth century. The fortification though knows significant alterations firstly by Serenissima Republic of Venice from the fifteenth century that aims to dominate the naval routes of Eastern Mediterranean by establishing a system of coastal fortifications and later by the Ottomans after the conquest of Venice's possessions at Messenia in 1500. Between fifteenth and seventeenth century, apart from important modifications at the initial enceinte of the northern Upper City, the most notable transformation of Old Navarino is the construction of the new Lower fortification area at the south and the southern outwork ending up to the coastline. Especially the Lower fortification is a sample of multiple and large-scale successive alterations for the adjustment to technological advances of artillery (fortification walls reinforcement, modification of tower-bastions, early casemates, gate complex enforcements). The current essay focuses on the study of these specific elements of the early artillery period and the examination of Old Navarino's strategic role at the time of transition before the adaptation of "bastion-front" fortification patterns, such as those experimented in the design of the fortified city of New Navarino, constructed at the opposite side of the Navarino gulf by the Ottomans (1573).
\end{abstract}

Keywords: Fortification, Ottoman, Venetian, early-artillery.

\section{Study's context}

Previous publications on Old Navarino fortification (Bon, 1969; Andrews, 2006; Papathanasopoulos, Papathanasopoulos, 2000; Zias, Kontogiannis, 2004; Kontogiannis, 2012) provide description of the fortification, important information on specific elements of architectural and archaeological interest as well as dating attempts for certain parts of the monument. The study on Ottoman Messenia during the eighteenth century also stresses out enlighting issues about population and strategic significance of Navarino (Zarinebaf, Bennet, Davis, 2005). However, researchers often mention particular difficulties on identification of building phases.
This is not irrelevant to the absence of a cumulative architectural documentation study for Old Navarino.

The scope of the current study is not to give the exact dating of the phases -this should be the goal of a complete monography. The article intends to stress out issues of artillery adaptation, complementary to previous publications, and observations based on the architectural survey, recently conducted in the frame of my ongoing $\mathrm{PhD}$ research on Ottoman fortification works at Peloponnese ${ }^{1}$. So far there was no other architectural survey material than the historical maps of Expédition scientifique de Morée (Blouet, 1831). 


\section{Historic frame}

The initial fortification activity on Koryphasio promontory dates back to the ancient period when Pylos city was built (Papathanasopoulos, Papathanasopoulos, 2000). Fragmental relics of the ancient fortifications or reused ancient material can be observed mainly at the northern section of the Upper enclosure. The knowledge of the transitional period between the ancient to the medieval times though is limited (Bon, 1969; Savvides, 1992-1993).

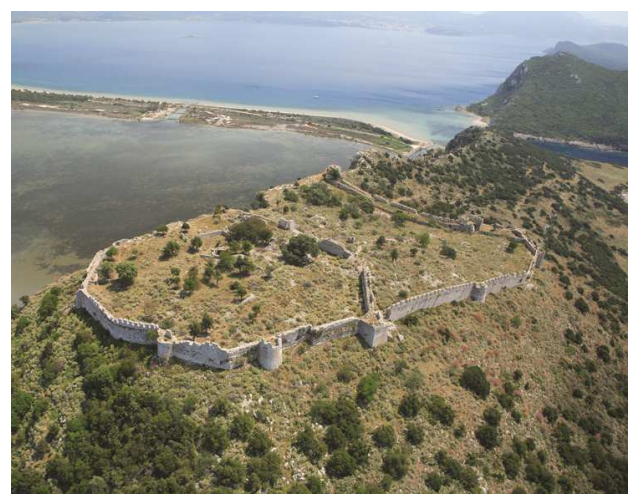

Fig. 1. View of the fortification from NW (Messenia Ephorate of Antiquities).

During the second half of the thirteenth century (1278) the spot becomes again an important position for the building of the so-called Avarinos fortification by Nicholas II St.Omer, Frankish ruler of the principality of Achaia, which according to previous studies is identified as today's Upper enclosure (Zias, Kontogiannis, 2004). Due to its strategic significance the following years the fortification changes hands between opposing powers, Genoese and different Frankish rivals until it is bought by Venetians in 1423 (Andrews, 2006; Perra, 2012).

Venetian interest for Old Navarino can be interpreted as a part of the broader defensive strategy for the protection of the Messenia coast. Modone and Coron function as the main city-ports of Serenissima in south-western Peloponnese and intermediate stops for the ships while smaller fortified positions are dependent on them (Nanetti, 2014). Old Navarino is dependent at the time by Modone and it serves to strengthen the control and defense of the area.

After the siege of Modone in 1500 Ottomans attack Old Navarino (in turkish: Anavarin-I atik) under Sultan Bayezid II and Venetians are forced to hand in the fortification. The following years Ottomans reinforce the fortification and install garrison and population to Navarino. The defeat of Ottomans in the battle of Lepanto and the following attack of 1572 to Navarino fortification by John of Austria, results to new measures of reinforcement of Navarino bay. Ottomans fill in the mouth of the northern sea passage (Andrews, 2006, p. 41; Wolpert, 2005, p. 229) and they build the fortification of New Navarino - Neokastro (in turkish: Anavarin-icedid) at the south of the bay, where population gradually settles.

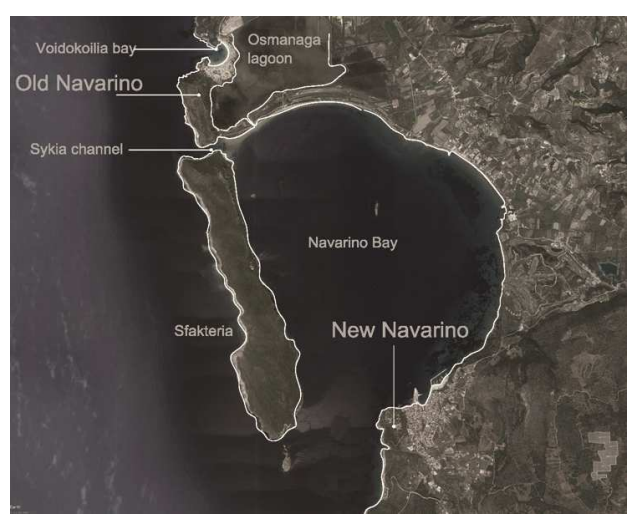

Fig. 2. Navarino bay (google maps, 2019).

After New Navarino's foundation, a small population and a garrison post still resides in Old Navarino. Evliya Çelebi's description who visits the area in 1668 gives a description of a vivid settlement at the Lower fortification and mentions the demolished walls of the Upper fortification (Celebi, 2005, pp. 72-79) ${ }^{2}$. The fortification passes to Venetians in 1686 who present plans for its reinforcement (Fig. 9) according to contemporary warfare updates (Andrews, 2006, p. 41). The second Ottoman occupation that begins in 1715 lasts till the Greek War of Independence. It seems that during this period the fortress despite its waning conditions (Wolpert, 
2005) has still military functions (Zarinebaf, Bennet, Davis, 2005, p. 165).

\section{General Description}

The fortification ${ }^{3}$ has unobstructed view to Navarino bay at the south, Voidokoilia coast at the north and Osmanaga Lagoon at the east. Between Koryphasio and Sfakteria Island which abstains only a few meters from its southern tip there is a small sea passage, the so-called Sykia channel.

The fortification consists of a northern polygonal Upper enclosure located at the highest peak of the mound and an outer L-shaped fortification line that covers the southern and south-western side of the rock. The abrupt ridge of the mound made it unnecessary to build a south-eastern defensive wall at the outer fortification. An additional defensive wall with an open-back tower connected with maritime installations stands at the southern coast of the promontory (Fig. 8) at the beginning of the cobbled path that leads to the fortification's entrance.
Despite that the medieval remnants which form the inner redoubt of the castle are dated back to the Frankish period, the majority of defensive works of the superstructure and the construction of the south -outer defensive walls can be attributed to the period of artillery establishment.

\subsection{Observations on the northern enclosure}

At the time of its construction the initial northern enclosure of polygonal shape should be a tall and thin curtain wall with square and round towers at the corners with a separate circuit (keep) at the south. The keep that was attached to the south wall of the Upper enclosure had an oblong shape with towers at the corners. The original gate should be probably placed at the west of the standing tower of the keep. According to Wolpert (2005, p. 237) the description of ottoman records agrees with Andrews' opinion (2006, p. 47) that the original gate was placed at the southern wall west of the towers as indicated in the plans of Grimani, published in 1706 (Fig. 9). This depiction differs from later Blouet's

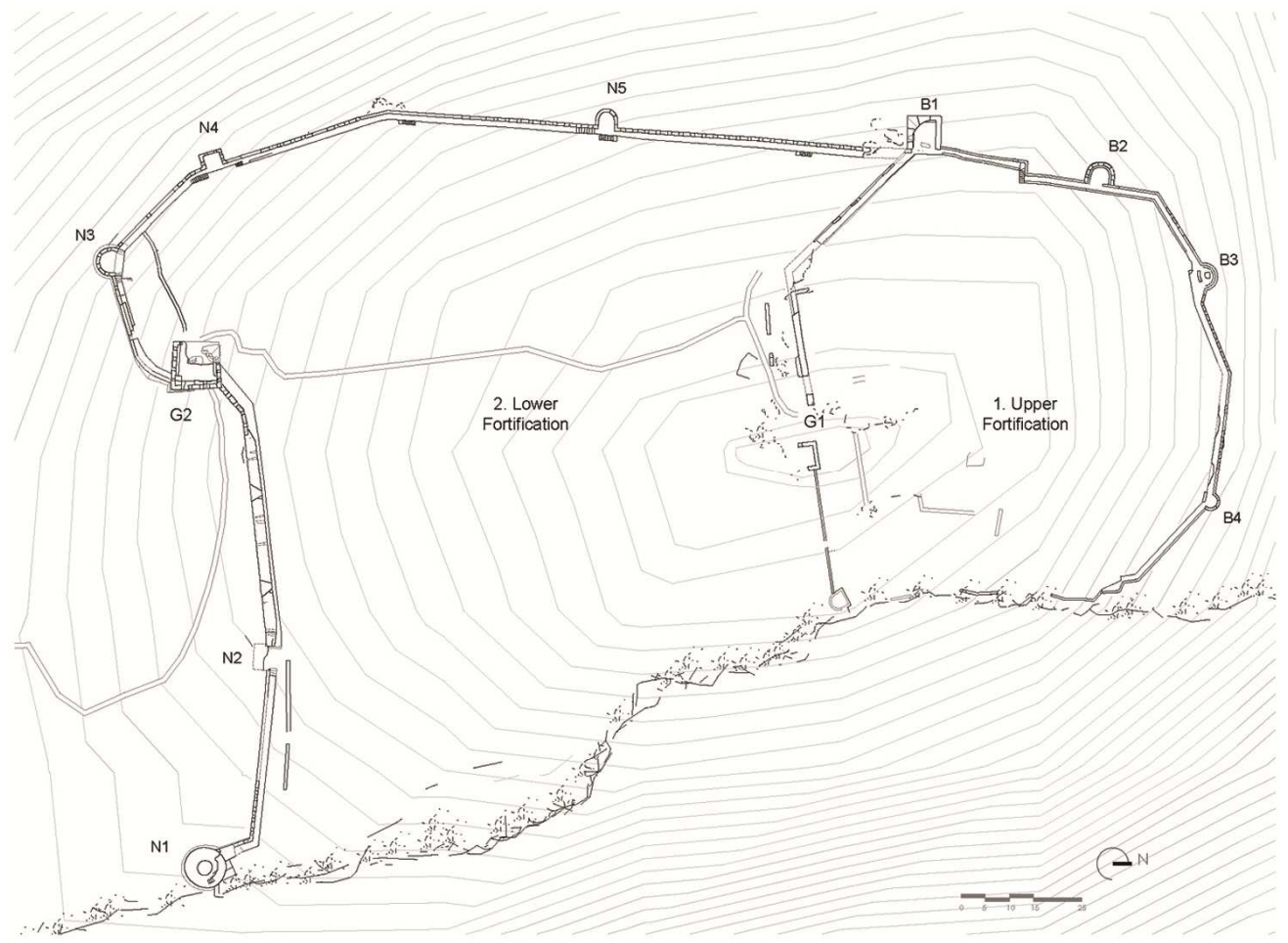

Fig. 3. General Ground Plan of Old Navarino (Simou, 2019). 

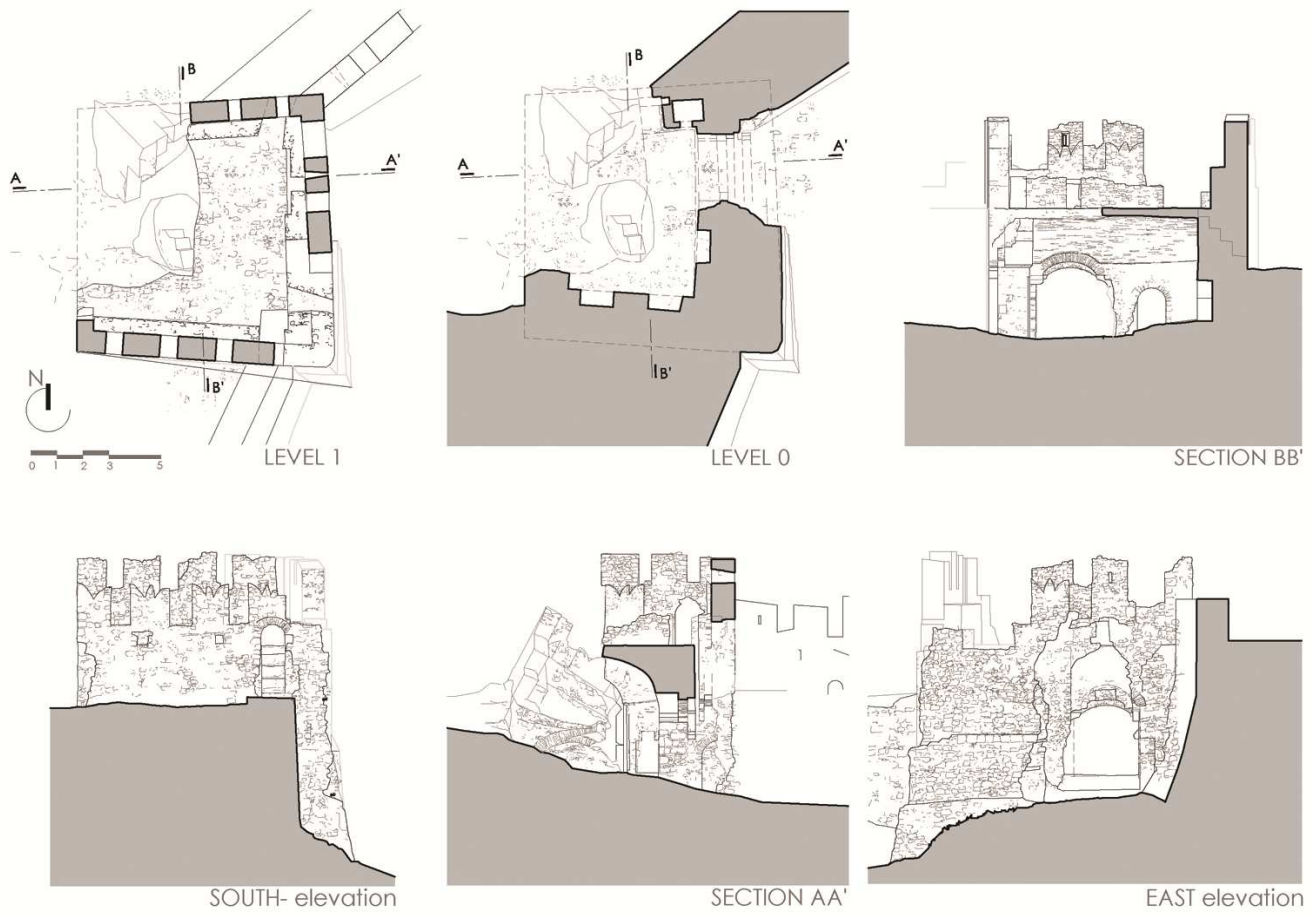

Fig. 4. Plans of the Gate Tower G2 (Simou, 2019).

survey (1831) that placed the gate between two square towers. Both sides of an apse of a collapsed arched gateway (G1) can be observed at this point. The springing line of this apse stands just a few centimeters above the current level of the steps of the paved stairway leading to the inner redoubt. The observation of the arch's morphological elements (G1) that are similar to those of the inner building layer of the southern gateway (G2) suggest that gate reinforcement works were done at both the north and south gateway, possibly at the same period of ottoman dominion.

The medieval towers of the inner enclosure (B1, B3, B4), based on ancient or reused ancient understructure $^{4}$ (Fig. 1) were adapted to artillery's demands in two major distinctive phases. The initial reaction to artillery technology was a strengthening of masonry's thickness and construction of casemates for small arms with characteristic circular carved-stone ouvertures de tirs. In a posterior phase the towers were filled up, the early cannon provisions were blocked and new cannon positions were built on the tow- ers' platforms. In order to hold heavy artillery the tower embrasures were then being heightened or modified while an additional masonry layer was added to the back side of the walls. The platform of the square tower B1 was modified for cannon embrasures.

Apart for the transformations of already existing towers, new provisions were also done such as the semi-round tower-bastion in the middle of the western wall (B2) of the inner enclosure. This addition of the first artillery period intended to cover a wider shot-range of the western part. It resembles to similar provisions of the outer fortification wall.

\subsection{Observations on the Sourthern fortifica- tion and south tower of Sykia channel}

The south - outer fortification sector is the part that received the majority of artillery interventions. Zias and Kontogiannis (2004) stated that the southern fortification was built by Venetians between 1440 and 1490 based on radiochronology dating techniques. According to Kontogiannis 
(2012) these walls that present typical characteristics of Venetian school that can be also found in Modone and Coron were developed in response to the augmentation of population and then adapted to artillery. This hypothesis that seems reasonable needs to be confirmed by a meticulous survey of building phases and research of early ottoman sources.

In the western sector of the outer fortification rises a wall of approximately $8 \mathrm{~m}$ height and $1,90 \mathrm{~m}$ width, interrupted by a round (N5) and a rectangular (N4) tower-bastion. Their platforms and parapet-walks with the notched crenellations are accessible through attached staircases on the back. In the middle of the southern sector stands the main gateway of the south enclosure (G2) splitting the defense line into two subdivisions (Fig. 4). The gate-tower is a two-storied rectangular edifice with complex building history. The original structure that has been partially embodied in posterior masonry had a gate placed at the east side supported by portcullis. Towers' façade was defined by a pair of arched door frames. Traces of the portcullis frame can be seen today. Its original floor was lower than the current floor level. The gate was heavily transformed in a phase that researchers agree that it belongs to the Ottoman period (Andrews, 2006, pp. 43-44; Kontogiannis, 2012, p. 40) based on the morphological characteristics of the masonry that can be also found in other Ottoman fortifications. New masonry was added to the interior chamber of the gateway that was covered by a barrel vault made completely out of brick. This masonry layer had niches and a small rectangular guard post inscribed in the walls, a reinforcement of the south door's frame with successive recessed arches and a second similar doorframe designed at the north wall of the tower (also similar to the traces of the doorframe of gate G1 at the Upper enclosure - already described). The tower was heightened by constructing of new shallow-tail merlons above the existing three- notched merlons.

The south defensive line that bends at the meeting point of the gate-tower $(\mathrm{G} 2)$ is protected by tower-bastions of the transitional artillery period at the east and west corners. The traces of another square tower (N2) -nowadays demolished- are also visible in the middle of the east subdivision.

The tower-bastions present typological and construction similarities. The two semi-rounded bastion-towers N3, N5 together with tower B2 of the inner enclosure have a 5-6 $\mathrm{m}$ dia (measured at the platforms' level) with estimated initial height around $7 \mathrm{~m}$ (Fig. 5) and are slightly scarped. The east round tower-bastion N1 (Fig. 6) has a diameter of $8,5 \mathrm{~m}$ and it is $7,5 \mathrm{~m}$ high. Its vaulted chamber is not accessible, but traces of its ceiling can be seen though an opening.
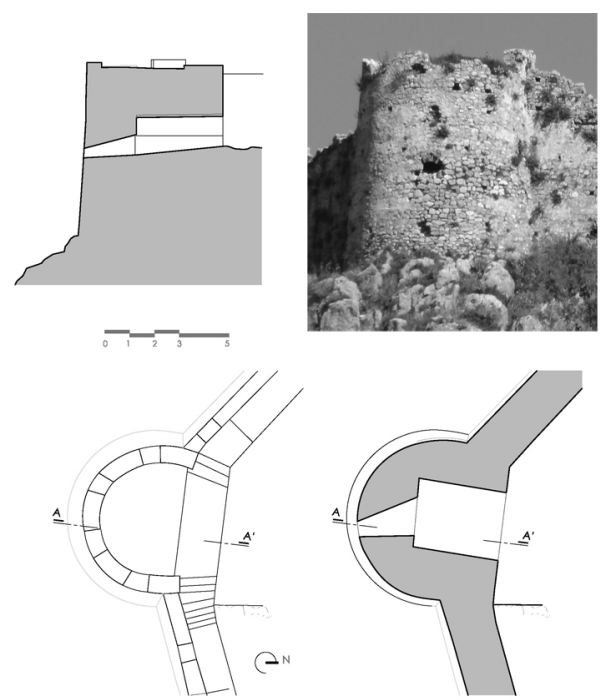

Fig. 5. Tower Bastion N3 (Simou, 2019).

The tower bastions had vaulted brick firing chambers of rectangular or trapezoidal plan, opened at the towers' back to create a level for the placement of small cannons around 3,5-4 m below the platform's level. Two of these are still open today (N3, N5), however their ouvertures de tirs (arched openings with radially positioned bricks) seem that have been repaired and adjusted in a posterior phase to host larger cannons. In the tower-bastions B2 and N1(Fig. 6) that were blocked and filled up, the initial external carved stone frames of cannon openings are kept untouched and can be observed today.

The south section of the outer fortification wall is pierced at a low level with a series of early period casemates protecting the south passage. The 
arched ouvertures de tirs are made of bricks, similar to those of tower-bastion N3 (Fig. 5) and can be seen today from the external side of the wall while the interior is backfilled or blocked with the batteries of the more mature phase of artillery. Those batteries belong to the phase that the shot level was moved to the tower-platforms. Then the small tower bastions' superstructure was transformed to offer elementary cannon positions between the crenellations while new sophisticated cannon embrasures where constructed at the spacious curtains that were widened. Those are also depicted at the historic plan of Grimani (1706).



Fig. 6. Round Tower-bastion N1 (Mamaloukos, 2012).

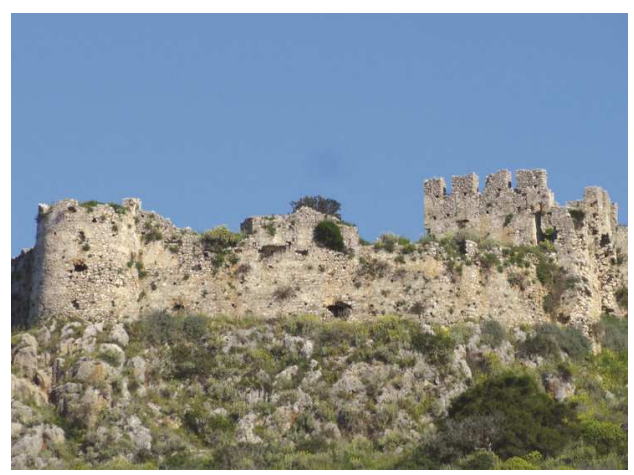

Fig. 7. West section of South Wall- tower-bastion N3 and Gate tower G2 (Simou, 2019).

At the entrance of the promontory (Fig. 8) stands an open back-tower of a horseshoe ground plan with a vaulted ceiling that hosts three early cannon positions. It is obvious that these openings were subject to widening modifications similar to those of the south sections. The tower faces and blocks the eastern side of the southern tip, protecting the entrance to the fortification from the Navarino bay.
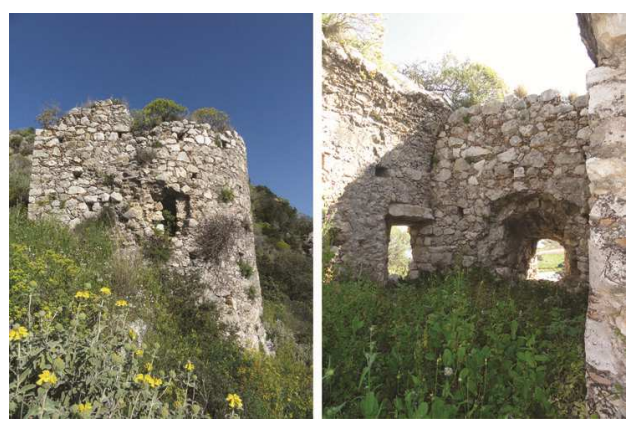

Fig. 8. Sourthern tower near Sykia channel (Simou, 2019).

\section{Artillery installation and strategic signifi- cance of Old Navarino}

The particular interest to strengthen the southern side of the fortification at the period of artillery is obvious by the successive reinforcements of the south division. The role of the fortification prior to Lepanto Battle was the control of the south naval passage of Sykia channel and the reinforcement of the southern fortification sector is possibly connected to this necessity (Wolpert, 2005, p. 224-232). The Sykia channel between Koryphasio and Sfakteria island was an important sea passage in the renown maritime route to the nearby anchorages of Navarino and Voidokoilia bay, referred to several portolans of the late medieval times and of the fifteenth century (Nanneti, 2011, pp. 138-141). After the siege of Navarino in 1572 by the Spanish navy this particular south port of Sykia spot, depicted at Snanocchi's valuable representation (Cámara, 2016), becomes a weak point of defense. The Ottomans' decision to fill it up with earth, and the construction of New Navarino fortification downsizes the strategic significance of Old Navarino's control point.

The study of Old Navarino case epitomizes what was the condition of the early years of artillery expansion in existing hilltop fortifications by the seaside the constant effort and agony of defenders to keep up with the war evolution by adapt- 
ing and re-adapting artillery provisions' shape and shot range. It presents a good example on understanding the shift of strategic character of medieval control points that kept a short of auxiliary military function even though they were set on the sideline in favor of the more sophisticated bastioned fortifications. Further elaboration of this preliminary architectural documentation together with understanding of the poorly studied fortified architecture of early artillery in Peloponnese could help in the future to clarify and contextualize the difficult issues of dating.

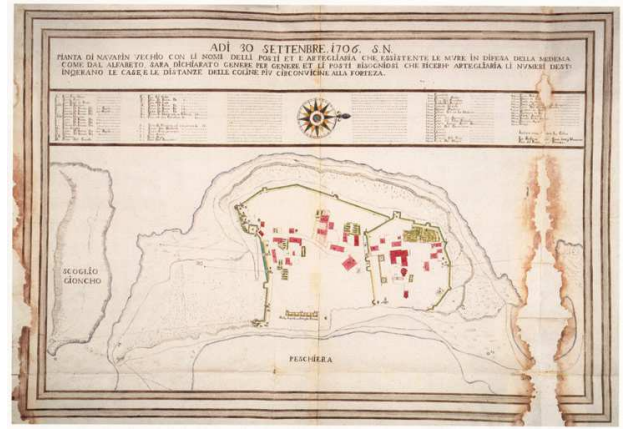

Fig. 9. Grimani Plan of Old Navarino,1706 (Andrews, 2006, Plate X).

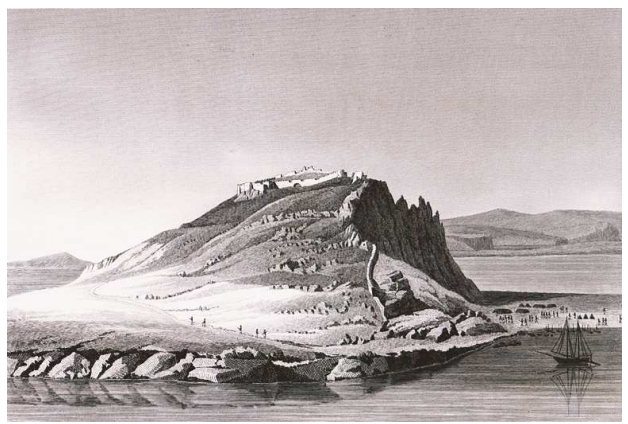

Fig. 10. Depiction of Old Navarino fortification, view from the south passage of Sykia channel (Blouet, 1831, Plate 5, Fig II).

\section{Acknowledgements}

I would like to express my gratitude to the Director and archaeologists of Ephorate of Antiquities of Messenia for the permission of conducting this research and my professors Stavros
Mamaloukos, Petros Koufopoulos and Elias Kolovos for their guidance and providing of study material. The measured survey that was done during March and September 2019 wouldn't be possible without the support of Thanasis Didaskalou and Theodora Zirogianni.

The $\mathrm{PhD}$ research is co-financed by Greece and the European Union (European Social FundESF) through the Operational Programme "Human Resources Development, Education and Lifelong Learning" in the context of the project "Strengthening Human Resources Research Potential via Doctorate Research" (MIS-5000432), implemented by the State Scholarships Foundation (IKY).

\section{Notes}

1 The dissertation on Ottoman fortification works in Peloponnese is conducted at the Department of Architecture, University of Patras under the supervision of professor Stavros Mamaloukos.

2 The analysis of the Ottoman cadastral records TT880 of the second Ottoman dominion in comparison with the traveler's Evliya Celebi description that is attempted by Wolpert, 2005 gives a more concrete view of the fortification's state in the seventeenth-eighteenth centuries.

${ }^{3}$ On a detailed description of Old Navarino fortification see: Andrews, 2006.

${ }^{4}$ Ancient relics can be also found at the lower building courses of the north and north-east section of the Upper enclosure and at the foundation of collapsed tower N2 of the Lower enclosure (Orlandos, 1959, pp. 148-149; Andrews, 2006, pp. 44, 48; Zias, Kontogiannis, 2004, p. 40; Kontogiannis, 2012, p. 297). 


\section{Bibliography}

Andrews, K. (2006). Castles of the Morea, Bugh. G. ed., American School of Classical Studies at Athens, Princeton New Jersey, pp. 40-48.

Blouet, A. (1831). Expédition scientifique de Morée, ordonnée par le gouvernement français. Architecture, sculptures, inscriptions et vues du Péloponèse, des Cyclades et de l'Attique. Volume I mesurées, dessinées, recueillies et publiées par Abel Blouet, Chez Firmin Didot Freres, Libraires, Paris.

Bon, A. (1969). La Morée franque: recherches historiques, topographiques et archéologiques sur la principauté d'Achaïe (1205-1430), E. de Boccard, Paris.

Cámara, A. (2016). "«Tengo Gran Macchina Di Cose Perr Intagliare...» [I Have a Large Collection of Things to Be Engraved...]. The Drawing of Commander Tiburzio Spannocchi, Chief Engineer of the Kingdoms of Spain", in Cámara, A. ed., Draughtsman Engineers Serving the Spanish Monarchy in the Sixteen to Eighteenth Centuries, Lecciones Juanelo Turriano de Historia de La Ingeniería, Fundación Juanelo Turriano, pp. 351-375.

Hale, J. (1965). "The Early Development of the Bastion: An Italian Chronology, c.1450-c.1534”, in Hale, J.; Highfield, J.; Beryl Smalley, eds., Europe in the Late Middle Ages, Faber Ed., pp. 466-517.

Kontogiannis, N. (2001). "Castles and fortifications in Messenia during Medieval and post-medieval period", in Peloponnesiaka 24, B, Athens, pp. 521-545.

Kontogiannis, N. (2012). "The fortification of Messenia from Byzantium to the Modern Greek State", in Doulaveras, A.; Spiliopoulou, I., eds., Messēnia: symvoles stēn historia kai ston politismo tēs, Papazisi Ed., Athens, pp. 285328.

Nanetti, A. (2011). Atlante Della Messenia Veneziana: Corone, Modone, Pilos e Le Loro Isole. Atlas of Venetian Messenia: Coron, Modon, Pylos and Their Islands. Atlas tēs Enetēkis Messēnias: Coronē, Methonē kē Nēsia tous: $1207-1500$ \& 1685-1715, La Mandragora, Imola.

Orlandos, A. (1959). To èrgon tès Archēologikis Eterēas kata to 1958, Athens.

Papathanasopoulos, G.; Papathanasopoulos, A. (2000). Pylos, Pylia, Odoiporiko sto Choro kai to Chrono, Tameio Archaiologikon Poron kai Apallotrioseon, Athens.

Perra, F. (2012). "Aspects of latin-dominated Messenia history The case of Navarino / Port de Jonc", in Doulaveras, A; Spiliopoulou, I., eds., Messēnia: symvoles stēn historia kai ston politismo tēs, Papazisi Ed., Athens, pp. 2538.

Savvides, A. (1992-1193). "On Pylos-Navarino-Zonklon in the byzantine period (late 6th -early 13th centuries)", Byzantina, 16, pp. 335-338.

Wolpert, A. (2005). "The Fortress of Anavarin-i Atik.”, in Zarinebaf, F.; Bennet, J.; Davis, J., eds., A Historical and Economic Geography of Ottoman Greece: The Southwestern Morea in the 18th Century, The American School of Classical Studies at Athens, pp. 223-240.

Zarinebaf, F.; Bennet, J.; Davis, J. (2005). A Historical and Economic Geography of Ottoman Greece: The southwestern Morea in the 18th century (Hesperia Supplement 34), ASCSA.

Zias, N.; Kontogiannis, N. (2004). "Kastro Paleou Navarinou: Ergasies ke porismata tēs periodou 2001-2003”, in Abstracts 24th, Symposium of Byzantine and Post-Byzantine Archaeology and Art, Athens, 7-9 May 2004, Christian Archaeological Society, Athens, pp. 40-41. 